\title{
PENYULUHAN MERAIH PRESTASI DENGAN JUJUR DAN PERKUAT INTEGRITAS
}

\author{
${ }^{1}$ Kharisma Danang Yuangga, ${ }^{2}$ Lia Asmalah, ${ }^{3}$ Aden Prawiro Sudarso \\ ${ }^{1}$ Dosen Fakultas Keguruan dan Ilmu Pendidikan Universitas Pamulang \\ ${ }^{2,3}$ Dosen Fakultas Ekonomi Universitas Pamulang \\ Email : 1 danangyuangga@gmail.com
}

\begin{abstract}
ABSTRAK
Tujuan yang ingin dicapai dalam kegiatan ini adalah untuk mengetahui bagaimana membangun peserta yayasan islamiyah ciputat yang sebagian besar adalah para pelajar untuk memahami pentingnya kejujuran untuk meraih prestasi dan memperkuat integritas, Sasaran dari program Pengabdian Masyarakat yang akan kami lakukan ini adalah para pelajar Yayasan Islamiyah Ciputat. Jln. Ki Hajar Dewantara No. 23. Ciputat. Tangerang Selatan

Metode pelaksanaan kegiatan dengan cara menggunakan teknik semiar, pemaparan secara langsung di ikuti oleh diskusi dan diakhiri dengan evaluasi.

Dengan kegiatan ini diharapkan para peserta dapat meraih prestasi dengan jujur dan perkuat integritas. Selama kegiatan berlangsung peserta memberikan tanggapan yang baik, hal ini dapat dilihat dari dukungan mereka dalam setiap kegiatan yang di adakan, sehingga dapat membantu para peserta dalam mempersiapkan masa depannya. Disarankan para peserta bisa mempertahankan integritas dan kejujuran demi meningkatkan kualitas diri.
\end{abstract}

\section{Kata Kunci : Prestasi, Jujur, Integritas}

\section{PENDAHULUAN}

Didirikan pada tahun 1965 oleh Drs. H. Zarkazih Noer yang mempelopori pembangunan Yayasan Islamiyah Ciputat ini. Awalnya proses kegiatan belajar mengajar terpaksa dilakukan di gedung sekolah swasta lain karena yayasan belum mempunyai gedung sendiri. Namun kini Yayasan Islamiyah Ciputat telah memiliki gedung sendiri.

Beberapa kegiatan ekstrakurikuler seperti paskibra, marawis atau futsal menjadi sarana bagi anak didik yayasan Islamiyah untuk menyalurkan minat, bakat dan kreatifitas mereka. Salah satu prestasi yang bisa dibanggakan dari yayasan ini yaitu Pasukan Pengibar Bendera Pusaka (PASKIBRAKA) SMA Islamiyah Ciputat pernah mewakili kabupaten Tangerang di tingkat nasional.

Mengedepankan pendidikan berorientasi pada prinsip-prinsip islam yang bernaungan IPTEK \& IMTAQ merupakan visi dari yayasan ini dalam mendidik dan membimbing anak didiknya agar menjadi insan-insan muda yang berkualitas, berprestasi serta berakhlak baik. Terlebih lagi dengan adanya dukungan i-Skola layanan info penting kepada Orangtua/ Wali murid. Diharapkan lulusan yayasan ini 
selain memiliki wawasan IPTEK yang luas juga memahami, mendalami dan menguasai kaidah serta ajaran Islam yang telah ditanamkan kepada mereka selama mengenyam bangku pendidikan di Yayasan Islamiyah Ciputat .

- Prestasi Belajar tidak dapat dipisahkan dari kegiatan belajar, karena belajar merupakan suatu proses, sedangkan prestasi belajar adalah hasil dari proses pembelajaran tersebut. Bagi seorang anak belajar merupakan suatu kewajiban. Berhasil atau tidaknya seorang anak dalam pendidikan tergantung pada proses belajar yang dialami oleh anak tersebut.

Prestasi adalah hasil yang telah dicapai seseorang dalam melakukan kegiatan. Gagne (1985:40) menyatakan bahwa Prestasi Belajar dibedakan menjadi lima aspek, yaitu : kemampuan intelektual, strategi kognitif, informasi verbal, sikap dan keterampilan. Menurut Bloom dalam Suharsimi Arikunto (2012:110) bahwa hasil belajar dibedakan menjadi tiga aspek yaitu kognitif, afektif dan psikomotorik.

Prestasi adalah hasil dari suatu kegiatan yang telah dikerjakan, diciptakan baik secara individu maupun secara kelompok (Djamarah, 2011:19).

Kata prestasi berasal dari bahasa Belanda "Prestasic" yang berarti hasil usaha. Dalam kamus besar Bahasa Indonesia Prestasi Belajar didefinisikan sebagai hasil penilaian yang diperoleh dari kegiatan persekolahan yang bersifat kognitif dan biasanya ditentukan melalui pengukuran dan penilaian.

Berdasarkan latar belakang yang dipaparkan di atas maka identifikasi masalah adalah peserta yayasan islamiyah ciputat yang sebagian besar adalah para pelajar cenderung kurang pemahaman pentingnya kejujuran untuk meraih prestasi dan memperkuat integritas.

\section{METODE PELAKSANAAN KEGIATAN}

Metode pelaksanaan kegiatan dengan cara menggunakan teknik semiar, pemaparan secara langsung di ikuti oleh diskusi dan diakhiri dengan evaluasi Hari Pertama.

1. Pembukaan dan Pembacaan Doa

2. Sambutan Ketua Pelaksana

3. Pemaparan Pengertian Prestasi Belajar Dan Bagaimana Cara

Mendapatkan Presatasi Belajar Yang Baik

4. Tanya Jawab dan Evaluasi

5. ISOMA

6. Doa Penutup

Hari Kedua

1. Pembukaan dan Pembacaan Doa

2. Pemaparan Pentingnya Kejujuran Dalam Kehidupan Sehari-Hari

3. Tanya Jawab dan Evaluasi

4. ISOMA

5. Doa Penutup

Hari Ketiga 
1. Pembukaan dan Pembacaan Doa

2. Pemaparan Penguatan Integritas

3. Tanya Jawab dan Evaluasi

4. ISOMA

5. Doa Penutup

\section{HASIL DAN PEMBAHASAN}

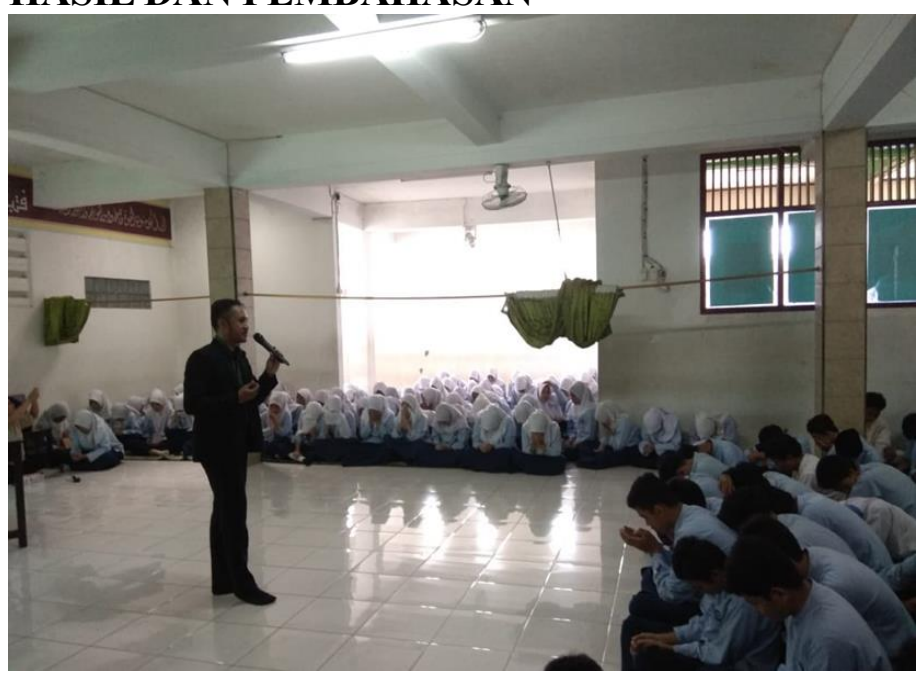

Terdapat lima nilai karakter utama yang bersumber dari Pancasila, yang menjadi prioritas pengembangan gerakan PPK; yaitu religius, nasionalisme, integritas, kemandirian dan kegotongroyongan. Masing-masing nilai tidak berdiri dan berkembang sendiri-sendiri, melainkan saling berinteraksi satu sama lain, berkembang secara dinamis dan membentuk keutuhan pribadi.

1. Nilai karakter religius mencerminkan keberimanan terhadap Tuhan yang Maha Esa yang diwujudkan dalam perilaku melaksanakan ajaran agama dan kepercayaan yang dianut, menghargai perbedaan agama, menjunjung tinggi sikap toleran terhadap pelaksanaan ibadah agama dan kepercayaan lain, hidup rukun dan damai dengan pemeluk agama lain. Implementasi nilai karakter religius ini ditunjukkan dalam sikap cinta damai, toleransi, menghargai perbedaan agama dan kepercayaan, teguh pendirian, percaya diri, kerja sama antar pemeluk agama dan kepercayaan, anti perundungan dan kekerasan, persahabatan, ketulusan, tidak memaksakan kehendak, mencintai lingkungan, melindungi yang kecil dan tersisih.

2. Nilai karakter nasionalis merupakan cara berpikir, bersikap, dan berbuat yang menunjukkan kesetiaan, kepedulian, dan penghargaan yang tinggi terhadap bahasa, lingkungan fisik, sosial, budaya, ekonomi, dan politik bangsa, menempatkan kepentingan bangsa dan negara di atas kepentingan diri dan kelompoknya. Sikap nasionalis ditunjukkan melalui sikap apresiasi budaya bangsa sendiri, menjaga kekayaan budaya bangsa, rela berkorban, unggul, dan berprestasi, cinta tanah air, menjaga lingkungan, taat hukum, disiplin, menghormati keragaman budaya, suku, dan agama.

3. Adapun nilai karakter integritas merupakan nilai yang mendasari perilaku yang didasarkan pada upaya menjadikan dirinya sebagai orang yang selalu dapat dipercaya dalam perkataan, tindakan, dan pekerjaan, memiliki komitmen dan kesetiaan pada nilai-nilai kemanusiaan dan moral. Karakter integritas meliputi 
sikap tanggung jawab sebagai warga negara, aktif terlibat dalam kehidupan sosial, melalui konsistensi tindakan dan perkataan yang berdasarkan kebenaran. Seseorang yang berintegritas juga menghargai martabat individu (terutama penyandang disabilitas), serta mampu menunjukkan keteladanan.

4. Nilai karakter mandiri merupakan sikap dan perilaku tidak bergantung pada orang lain dan mempergunakan segala tenaga, pikiran, waktu untuk merealisasikan harapan, mimpi dan cita-cita. Siswa yang mandiri memiliki etos kerja yang baik, tangguh, berdaya juang, profesional, kreatif, keberanian, dan menjadi pembelajar sepanjang hayat.

5. Nilai karakter gotong royong mencerminkan tindakan menghargai semangat kerja sama dan bahu membahu menyelesaikan persoalan bersama, menjalin komunikasi dan persahabatan, memberi bantuan/pertolongan pada orang-orang yang membutuhkan. Diharapkan siswa dapat menunjukkan sikap menghargai sesama, dapat bekerja sama, inklusif, mampu berkomitmen atas keputusan bersama, musyawarah mufakat, tolong menolong, memiliki empati dan rasa solidaritas, anti diskriminasi, anti kekerasan, dan sikap kerelawanan.

Penguatan Tri Pusat Pendidikan "PPK ini merupakan pintu masuk untuk melakukan pembenahan secara menyeluruh terhadap pendidikan kita," disampaikan Mendikbud kepada Tim Implementasi PPK yang terdiri dari berbagai unsur pemangku pendidikan beberapa waktu yang lalu.

Menurut Mendikbud, PPK tidak mengubah struktur kurikulum, namun memperkuat Kurikukum 2013 yang sudah memuat pendidikan karakter itu. Dalam penerapannya, dilakukan sedikit modifikasi intrakurikuler agar lebih memiliki muatan pendidikan karakter. Kemudian ditambahkan kegiatan dalam kokurikuler dan ekstrakurikuler. Integrasi ketiganya diharapkan dapat menumbuhkan budi pekerti dan menguatkan karakter positif anak didik.

"Prinsipnya, manajemen berbasis sekolah, lalu lebih banyak melibatkan siswa pada aktivitas daripada metode ceramah, kemudian kurikulum berbasis luas atau broad based curriculum yang mengoptimalkan pemanfaatan sumber-sumber belajar," tutur Mendikbud.

"Peran guru sangat penting dalam pendidikan dan ia harus menjadi sosok yang mencerahkan, yang membuka alam dan pikir serta jiwa, memupuk nilai-nilai kasih sayang, nilai-nilai keteladanan, nilai-nilai perilaku, nilai-nilai moralitas, nilainilai kebhinnekaan. Inilah sejatinya pendidikan karakter yang menjadi inti dari pendidikan yang sesungguhnya," disampaikan Presiden Joko Widodo dalam pembukaan Rembuk Nasional Pendidikan dan Kebudayaan 2017 beberapa waktu yang lalu.

Tak hanya sebagai pengajar mata pelajaran saja, namun guru mampu berperan sebagai fasilitator yang membantu anak didik mencapai target pembelajaran. Guru juga harus mampu bertindak sebagai penjaga gawang yang membantu anak didik menyaring berbagai pengaruh negatif yang berdampak tidak baik bagi perkembangannya. Seorang guru juga mampu berperan sebagai penghubung anak didik dengan berbagai sumber-sumber belajar yang tidak hanya ada di dalam kelas atau sekolah. Dan sebagai katalisator, guru juga mampu menggali dan 
mengoptimalkan potensi setiap anak didik.

Saat ini, melalui revisi Peraturan Pemerintah Nomor 64 Tahun 2008 menjadi PP Nomor 19 Tahun 2017, Kemendikbud mendorong perubahan paradigma para guru agar mampu melaksanakan perannya sebagai pendidik profesional yang tidak hanya mampu mencerdaskan anak didik, namun juga membentuk karakter positif mereka agar menjadi generasi emas Indonesia dengan kecakapan abad ke-21.

\section{KESIMPULAN DAN SARAN}

Pelaksanaan kegiatan pengabdian masyarakat oleh lembaga penelitian dan pengembangan masyarakat (LPPM) Universitas Pamulang yang dilakukan oleh dosendosen program studi manajemen telah berjalan dengan lancar dan mendapat sambutan hangat dari tempat pelaksanaan kegiatan ini yaitu para peserta Yayasan Islamiyan, Ciputat - Tangerang Selatan.

Dengan ada nya kegiatan ini menjadikan para peserta dapat meraih prestasi


dengan jujur dan perkuat integritas. Selama kegiatan berlangsung peserta memberikan tanggapan yang baik, hal ini dapat dilihat dari dukungan mereka dalam setiap kegiatan yang di adakan, sehingga dapat membantu para peserta dalam mempersiapkan masa depannya.

Disarankan para peserta bisa mempertahankan integritas dan kejujuran demi meningkatkan kualitas diri.

\section{DAFTAR PUSTAKA}

Arikunto, Suharsimi. 2012. Prosedur Penelitian Suatu Pendekatan Praktik. Jakarta: RinekaCipta.

Djamarah, Syaiful Bahri. 2011. Psikologi Belajar. Jakarta : Rineka Cipta

Gagne, R.M. 1985. The Condition of Learning Theory of Instrucion. New York: Rinehart.

Hamalik, Oemar. 2001. Metode Belajar dan Kesulitan Belajar. Bandung: Tarsito.

Sunarsi, D., \& Asmalah, L. (2018). Pelatihan Manajemen Pengembangan Diri Bagi Penerima Beasiswa RZIS UGM Dan Dompet Shalahuddin Jogjakarta. Jurnal Pengabdian Dharma Laksana, 1(1). 